\title{
Penerapan PHBS Kesehatan Gigi dan Gosok Gigi Massal
}

\author{
Najihah \\ Universitas Borneo Tarakan, Jl. Amal Lama No. 01, Kota Tarakan, Kalimatan Utara, Indonesia 77115 \\ *e-mail:714.najihah@gmail.com
}

\begin{abstract}
Abstrak
Munculnya berbagai penyakit yang sering menyerang anak usia sekolah (6-10 tahun) ternyata umumnya berkaitan dengan Perilaku Hidup Bersih dan Sehat (PHBS). Beberapa anak menunjukkan perilaku yang tidak sehat seperti lebih suka menkonsumsi makanan yang tidak sehat yang tinggi lemak, gula, garam, rendah serat, meningkatkan risiko hipertensi, diabetes mellitus, obesitas dan sebagainya. Selain itu, ditemukan pula anak yang tidak menggosok gigi pada saat mandi dan sebelum tidur sehingga gigi mereka berlubang. Kondisi tersebut harus segera diantisipasi dengan meningkatkan pola hidup sehat melalui PHBS. Berdasarkan survei dan wawancara yang dilakukan kepada siswa di SD Negeri Bontojai di desa Bontokassi mengatakan tidak mengetahui cara menggosok gigi dengan baik dan benar. Program pengabdian masyarakat ini bertujuan untuk meningkatkan pengetahuan dan derajat kesehatan siswa siswi di SD Negeri Bontojai dengan melakukan penyuluhan kesehatan gigi dan cara gosok gigi yang benar dan kegiatan gosok gigi massal. Penyuluhan PHBS Kesehatan Gigi dan Gerakan Gosok Gigi Massal efektif untuk mewujudkan pendidikan kesehatan untuk menanamkan nilai-nilai PHBS sehingga berpotensi sebagai change agent untuk mempromosikan PHBS baik di lingkungan sekolah, keluarga maupun masyarakat.
\end{abstract}

Kata Kunci: Gosok Gigi Massal, Kesehatan Gigi, Penyuluhan PHBS

\section{Pendahuluan}

Perilaku Hidup Bersih dan Sehat (PHBS) adalah bentuk perwujudan paradigma sehat dalam budaya perorangan, keluarga, dan masyarakat yang berorientasi sehat, bertujuan untuk meningkatkan, memelihara, dan melindungi kesehatannya baik fisik, mental, spiritual, maupun sosial. Selain itu juga program perilaku hidup bersih dan sehat bertujuan memberikan pengalaman belajar atau menciptakan suatu kondisi bagi perorangan, kelompok, keluarga, dengan membuka jalur komunikasi, informasi, dan edukasi untuk meningkatkan pengetahuan, sikap, dan perilaku sehingga masyarakat sadar, mau, dan mampu mempraktikkan perilaku hidup bersih dan sehat melalui pendekatan pimpinan (advocacy), bina suasana (social support), dan pemberdayaan masyarakat (empowerment). Dengan demikian masyarakat dapat mengenali dan mengatasi masalahnya sendiri (Depkes RI, 2007).

Pembangunan kesehatan bertujuan meningkatkan kesadaran, kemampuan dan kemauan hidup sehat bagi setiap penduduk agar dapat mewujudkan derajat kesehatan yang setinggi-tingginya. Masyarakat diharapkan mampu berperan sebagai pelaku pembangunan kesehatan dalam menjaga, memelihara dan meningkatkan derajat kesehatannya sendiri serta berperan aktif dalam mewujudkan kesehatan masyarakat. Harapan tersebut dapat terwujud apabila masyarakat diberdayakan sepenuhnya dengan sumber daya dimilikinya untuk dapat menerapkan PHBS dalam kehidupan sehari-hari, baik di rumah, di sekolah, di tempat kerja. PHBS yang harus dilakukan oleh setiap individu/keluarga/kelompok sangat banyak, dimulai dari bangun tidur sampai dengan tidur kembali. PHBS adalah sekumpulan perilaku yang dipraktekkan atas dasar kesadaran sebagai hasil pembelajaran yang menjadikan individu/keluarga/kelompok dapat menolong dirinya sendiri dalam bidang kesehatan dan berperan aktif dalam mewujudkan derajat kesehatan masyarakat.

Profil Kesehatan Indonesia tahun 2009 menyajikan data bahwa baru 64.41\% sarana yang telah dibina kesehatan lingkungaannya, yang meliputi instansi pendidikan $67.52 \%$, tempat kerja $59.15 \%$, tempat ibadah $58.84 \%$, fasilitas kesehatan $77.02 \%$ dan sarana lain 62.26\%. Hal ini menunjukkan bahwa pembinaan PHBS di tatanan instansi pendidikan, belum berjalansebagaimana mestinya. Dengan demikian diperlukan pendekatan yang paripurna (komprehensif), lintas program dan lintas sektor (Kemenkes RI, 2011).

Seiring dengan era globalisasi, kebiasaan yang dapat mengancam kesehatan peserta didik juga semakin meningkat. Munculnya berbagai penyakit yang sering menyerang anak usia sekolah (6-10 tahun) ternyata umumnya berkaitan dengan PHBS. Oleh karena itu, penanaman nilai-nilai PHBS di sekolah merupakan kebutuhan mutlak dan dapat dilakukan melalui pendekatan UKS. Beberapa anak yang menunjukkan perilaku yang tidak sehat seperti lebih suka menkonsumsi makanan yang tidak sehat yang tinggi lemak, gula, garam, rendah serat, meningkatkan risiko hipertensi, diabetes mellitus, obesitas dan sebagainya (Kemenkes RI, 2011).

Kondisi tersebut harus segera diantisipasi dengan meningkatkan pola hidup sehat melalui PHBS. Pemeliharaan kesehatan anak ditujukan untuk mempersiapkan generasi yang akan datang yang sehat, cerdas, dan berkualitas serta untuk menurunkan angka kematian anak. Institusi pendidikan dipandang sebagai sebuah tempat yang strategis untuk 
mempromosikan kesehatan. Sekolah juga merupakan institusi yang efektif untuk mewujudkan pendidikan kesehatan, dimana peserta didik dapat diajarkan tentang maksud perilaku sehat dan tidak sehat serta konsekuensinya. Selain itu, usia sekolah merupakan masa keemasan untuk menanamkan nilai-nilai PHBS dan berpotensi sebagai change agent untuk mempromosikan PHBS baik di lingkungan sekolah, keluarga maupun masyarakat (Adiwiryono, 2010)

Hasil survei dan wawancara yang dilakukan kepada siswa di SD Negeri Bontojai di desa Bontokassi mengatakan tidak mengetahui cara menggosok gigi dengan baik dan benar serta tampak beberapa siswa memiliki gigi berlubang. Berdasarkan hasil studi pendahuluan tersebut, maka dilakukan upaya dalam peningkatan pengetahuan dan derajat kesehatan siswa siswi di SD Negeri Bontojai di desa Bontokassi dengan melakukan Penerapan PHBS Kesehatan Gigi dan gerakan gosok gigi massal.

\section{Metode}

a. Pengenalan dan Persiapan

Mitra utama dalam kegiatan ini adalah Pemerintah Kabupaten Gowa. Dimana dinas terkait merupakan leading sector program ini, sedangkan Kantor kelurahan/desa dan kecamatan merupakan ujung tombak sukses dan tidaknya pelaksanaan program ini.

Selanjutnya sasaran kegiatan ini adalah masyarakat Desa Bontokassi Kecamatan Parangloe Kabupaten Gowa. Sasaran utama program ini yaitu kelompok anak usia sekolah, dalam hal ini adalah siswa siswi SD Negeri Bontojai.

b. Mekanisme pelaksanaan pengabdian masyarakat

Berdasarkan hasil identifikasi masalah mitra, maka metode yang digunakan dalam meningkatkan derajat kesehatan siswa siswi tersebut ialah dengan penyuluhan tentang PHBS tentang kesehatan gigi dan gerakan gosok gigi massal.

1. Penyuluhan PHBS Kesehatan Gigi

a. Tujuan Kegiatan

Meningkatkan pengetahuan seluruh siswa tentang PHBS kesehatan gigi dan cara gosok gigi yang baik dan benar

b. Isi Kegiatan

Pemberian pendidikan kesehatan tentang PHBS cara gosok gigi yang benar

c. Strategi

Ceramah, Diskusi, Demonstrasi

d. Evaluasi

Dilakukan pre dan posttest untuk melihat perubahan pengetahuan sebelum dan setelah dilaksanakan penyuluhan PHBS Kesehatan gigi.

2. Gerakan Gosok Gigi Massal

a. Tujuan Kegiatan

Meningkatkan pengetahuan seluruh siswa tentang PHBS cara gosok gigi yang baik dan benar

b. Isi Kegiatan

Mempraktekkan cara gosok gigi yang benar

c. Strategi

Demonstrasi, Praktik, Pendampingan

d. Evaluasi

Dilakukan pendampingan pada saat melakukan gosok gigi dan menilai cara siswa siswi melakukan gosok gigi yang baik dan benar.

\section{Hasil}

a. Karakteristik Peserta

Peserta dalam penyuluhan PHBS tentang gosok gigi yang benar dan gerakan gosok gigi massal ini adalah seluruh siswa siswi SD Negeri Bontojai yang hadir di lokasi pada saat dilakukan kegiatan.

b. Respon Peserta

Seluruh peserta yang hadir sangat antusias mengikuti kegiatan penyuluhan PHBS tentang kesehatan gigi dan gerakan gosok gigi massal ini. Pada saat penyuluhan sebagian besar peserta dapat mendemonstrasikan kembali cara gosok gigi yang baik dan benar. Hal yang sama ditunjukkan para peserta saat kegiatan gerakan gosok gigi massal.

c. Luaran kegiatan

PHBS adalah sekumpulan perilaku yang dipraktekkan atas dasar kesadaran sebagai hasil pembelajaran, yang menjadikan seseorang, keluarga, kelompok atau masyarakat mampu menolong dirinya sendiri (mandiri) di pelayanan kesehatan dan berperan aktif dalam mewujudkan kesehatan masyarakat (Kemenkes RI, 2011)

Kebersihan diri adalah upaya individu dalam memelihara kebersihan diri yang meliputi kebersihan rambut, gigi dan mulut, mata, telinga, kuku, kulit, dan kebersihan dalam berpakaian dalam meningkatkan kesehatan yang optimal. 
Memeliharaan kebersihan diri berarti tindakan memelihara kebersihan dan kesehatan diri seseorang untuk kesejahteraan fisik dan psikisnya. Seseorang dikatakan memiliki personal hygiene baik apabila, orang tersebut dapat menjaga kebersihan tubuhnya yang meliputi kebersihan kulit, kuku, rambut, mulut dan gigi, kebersihan dan kerapian pakaiannya, kebersihan mata hidung dan telinga serta kebersihan alat kelaminnya.

Masalah kesehatan umum yang terjadi pada anak usia sekolah biasanya berkaitan dengan kebersihan perorangan dan lingkungan seperti gosok gigi yang baik dan benar. Banyak anak usia sekolah yang menderita gigi berlubang akibat mengkomsumsi jajanan yang banyak mengandung gula. Akibatnya gigi mereka mudah rusak dan berlubang.

Masalah-masalah tersebut timbul karena kurangnya pengetahuan serta kesadaran akan pentingnya kesehatan terutama kebiasaan menggosok gigi dengan benar. Gosok gigi merupakan salah satu solusi yang murah dan efektif dalam pencegahan penyakit. Namun hingga saat ini kebiasaaan tersebut sering kali dianggap remeh.

Penyakit-penyakit yang timbul tersebut akan mempengaruhi tumbuh kembang anak sehingga mengakibatkan proses belajar mengajar terganggu. Penyuluhan Hidup Bersih dan Sehat bertujuan agar siswa mampu memahami pentingnya hidup bersih dan sehat yang meliputi; (1) Mengetahui cara gosok gigi yang baik dan benar; (2) Mengetahui manfaat gosok gigi yang baik dan benar; dan (3) Demonstrasi gosok gigi yang baik dan benar

1. Penyuluhan PHBS Kesehatan Gigi

Penyuluhan tentang Perilaku Hidup Bersih dan Sehat dilaksanakan pada hari Sabtu, 24 Januari 2015 mulai pukul 09.00 - 11.00 WITA di SD Negeri Bontojai Desa Bontokassi. Siswa-siswi yang mengikuti penyuluhan kesehatan tampak antusias menyimak apa yang disampaikan. Mereka juga mampu mendemonstrasikan cara menggosok gigi yang baik dan benar.

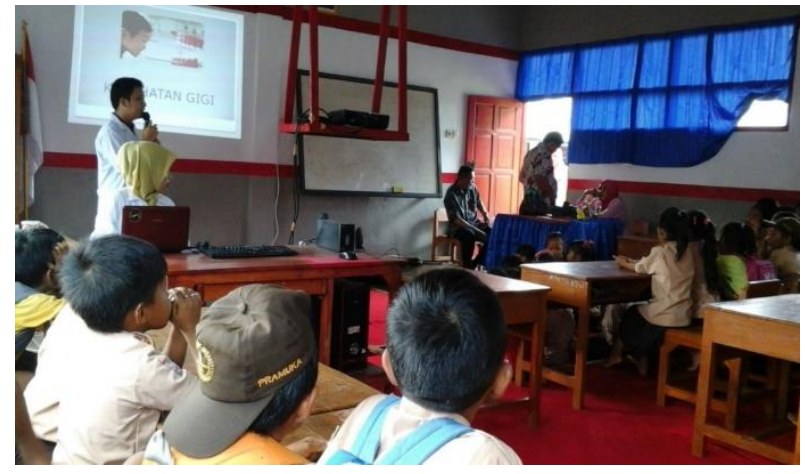

Gambar 1 Penyuluhan Kesehatan Gigi

Evaluasi tentang materi penyuluhan dilakukan dengan mengadakan posttest. Siswa siswi yang mampu menjawab pertanyaan dengan baik dan benar diberikan penghargaan. Dari hasil evaluasi tersebut, $90 \%$ siswa siswi mampu memahami tentang cara menggosok gigi yang benar.

2. Gerakan Gosok Gigi Massal

Pemahaman yang lebih mendalam terkait PHBS terkait gosok gigi yang benar dilakukan dengan kegiaran demontrasi. Demonstrasi gosok gigi yang baik dan benar dilakukan pada hari Sabtu, 07 Februari 2015 di SD Negeri Bontojai Desa Bontokassi. Pada awal kegiatan dilakukan pengkajian terhadap tingkat pengetahuan siswa tentang cuci gosok gigi. Setelah mengkaji pengetahuan siswa tentang gosok gigi, dan memberikan pengetahuan tentang gosok gigi yang baik dan benar. Pada pukul 09.30 WITA dimulai dengan gosok gigi massal yang dilakukan secara bersamaan, kegiatan ini berlangsung selama 30 menit. Waktu kegiatan gosok gigi massal sesuai dengan waktu yang kami rencanakan sebelumnya yaitu 30 menit. 

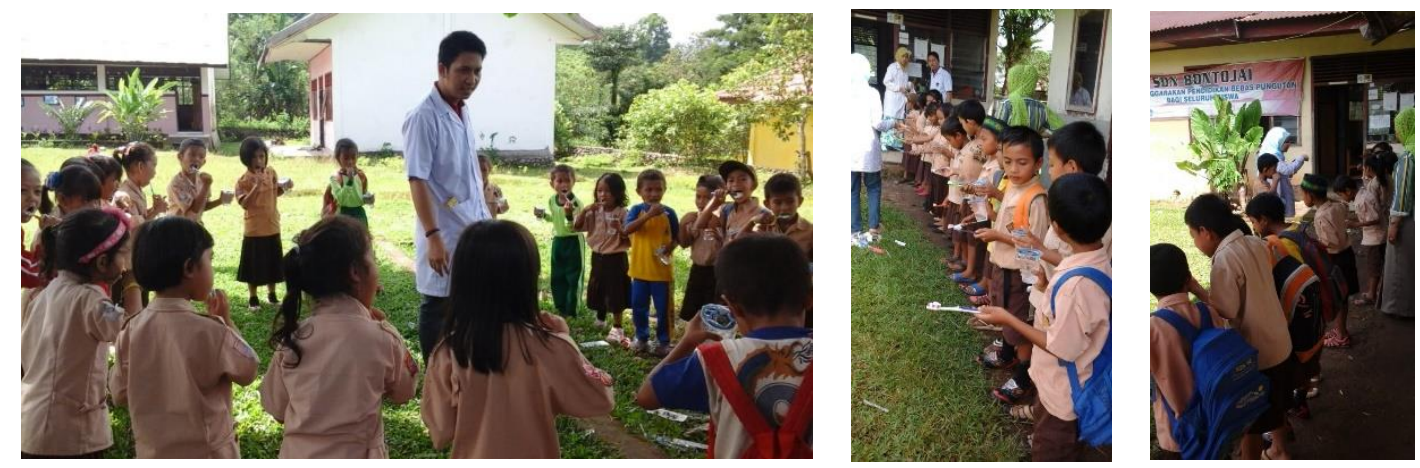

Gambar 2 Gerakan Gosok Gigi Massal

Semua siswa siswi mengikuti kegiatan dengan antusias. Siswa siswi didampingi dalam melakukan kegiatan gosok gigi sehingga dapat melakukan dengan baik dan benar.

\section{Kesimpulan}

Penyuluhan PHBS dapat meningkatkan pengetahuan dan sikap siswa siswi untuk meningkatkan derajat kesehatannya. Oleh karena itu, sekolah merupakan tempat yang efektif untuk mewujudkan pendidikan kesehatan untuk menanamkan nilai-nilai PHBS salah satunya dengan pemberian penyuluhan tentang kesehatan gigi dan cara gosok gigi yang baik dan benar sehingga berpotensi sebagai change agent untuk mempromosikan PHBS baik di lingkungan sekolah, keluarga maupun masyarakat.

\section{Saran}

Diharapkan pihak terkait terutama bapak/ibu guru mengingatkan siswa SD untuk melakukan PHBS yaitu menggosok gigi dengan baik dan benar. Hal ini perlu diperhatikan harus diperhatikan oleh siswa SD agar terhindar dari penyakit khususnya terkait penyakit gigi dan mulut. Selanjutnya dapat dilakukan kegiatan pemeriksaan kesehatan gigi pada siswa siswi SD.

\section{Daftar Pustaka}

Adiwiryono, RM. 2010. Pesan Kesehatan :Perilaku Hidup Bersih dan Sehat (PHBS) Anak Usia Dini dalam Kurikulum Pendidikan Anak Usia Dini. Jurnal Ilmu Kesehatan Universitas Muhammadiyah Prof. Hamka

Depkes RI. 2007. Panduan Promosi Kesehatan di Sekolah. Departemen Kesehatan RI, Jakarta

Kemenkes RI. 2011. Pedoman Umum Perilaku Hidup Bersih dan Sehat (PHBS), Kementrian Kesehatan RI. Jakarta

Profil Kesehatan Indonesia. 2013. Departemen Kesehatan RI: Jakarta

Riset Kesehatan Dasar (Riskesdas). 2013. Badan Penelitian dan Pengembangan Kesehatan Kementerian RI tahun 2014. Diakses: 19 Juni 2015, dari http://www.depkes.go.id/resources/download/general/Hasil\%20Riskesdas\%202013.pdf. 